\title{
Market Deregulation, Trade Liberalization and Productive Efficiency in Bangladesh Agriculture: An Empirical Analysis
}

\author{
Ruhul A. Salim ${ }^{1}$ \\ Curtin Business School (CBS) \\ Curtin University of Technology \\ Perth, WA 6845, Australia \\ and \\ M. Amzad Hossain \\ Department of Economics \\ University of Manitoba \\ Winnipeg, MB, Canada R3T 2N2 \\ e-mail: umhossam@cc.umanitoba.ca
}

\footnotetext{
${ }^{1}$ Corresponding address: School of Economics \& Finance, Curtin Business School (CBS), P. O. Box U1987, Curtin University of Technology, WA-6845, Australia. Phone: (08) 9266 4577, Fax: (08) 9266 3026. E-mail: Ruhul.Salim@cbs.curtin.edu.au
} 


\title{
Market Deregulation, Trade Liberalization and Productive Efficiency in Bangladesh Agriculture: An Empirical Analysis
}

\begin{abstract}
The impact of trade liberalization and of market deregulation in general, on the performance of agriculture remains contentious and empirical issue in the literature. Following the random coefficient frontier modelling framework, this paper attempts to contribute to this debate by computing the farm-specific productive efficiency indices in Bangladesh agriculture before and after reform. It also examines the impact of some farm-specific and policy variables on productive efficiency. The empirical results show that there are wide variations in productive efficiency across farms and regions and the average efficiency of all regions increased modestly by 8 percentage points from the pre-reform to post-reform period. The efficiency differentials are largely explained by farm size, infrastructure, households’ off-farm income and the reduction of government anti-agricultural bias in relation to trade and domestic policies. The implication of these results suggests the need for further reform to augment productive efficiency.
\end{abstract}

Keywords: Productive efficiency, Frontier production function, Trade liberalization JEL Classification: C20; D24; O24 


\section{Market Deregulation, Trade Liberalization and Productive Efficiency in Bangladesh Agriculture: An Empirical Analysis}

\section{Introduction}

Historically, the agricultural sector has been highly protected both in developed and developing economies. However, since the 1980s with the re-emergence of the neoclassical orthodoxy as the 'new' development paradigm, many developing countries adopted market reform and trade liberalization programs. The aims of these programs were to reduce government control in both agricultural input and output market, lowering tariffs and non-tariff barriers (NTBs) and allowing market forces work in agriculture. These programs often came as a part of Structural Adjustment Policy (SAP) with the conditionalities attached by the international donor agencies, such as the World Bank and the IMF. ${ }^{2}$ Like many other developing countries Bangladesh also initiated liberalization reform under the SAP program in the early 1980s. However, the yield per hectare remains lower in Bangladesh than in other Asian countries with comparable environment even after the implementation of market reform and trade liberalization nearly two decades ago. For example in 2001, average paddy production per hectare was 6062 KGs in China, 4515 in Indonesia, 3129 in Malaysia, 2856 in Philippines and 2811 in India while 2792 KGs in Bangladesh (FAO 2001). The logical question arises then whether market reform and trade liberalization indeed stimulated production environment and production efficiency in agriculture. This has been a subject of lively and often contentious debate, but still, remains an empirical issue in the literature. This study attempts to contribute to this debate by computing productive efficiency before and after liberalization reform using household data of Bangladesh agriculture. Since the identification of the sources of productive efficiency is critically important for policy purposes this study also explores the impact of farm-specific characteristics and some policy variables on farm level productive efficiency.

Studies on the measurement of productive efficiency using agriculture data are voluminous in the literature. However, studies on Bangladesh agriculture are limited to Sharif and Dar (1996), Wadud and White (2000), Coelli, et al (2002) and the more recent one, Rahman (2003). Although these studies bear significance as the earlier

\footnotetext{
${ }^{2}$ International donor agencies guided developing economies in the direction of outward orientation by reducing relative price distortions in the domestic market and promoting trade liberalization and linked financial loans to the progress of these policy reforms.
} 
studies in Bangladesh, however, they suffer from the following drawbacks. First, these studies used survey data from one or two or some villages (small administrative unit) of a particular region without covering the whole country. Second, these studies applied either the non-parametric or the conventional stochastic frontier models, which do not take into account individual input response (arising from the application of input) to output in measuring productive efficiency. Third, the stochastic frontier models arbitrarily impose a particular distribution for the farm-specific performance related error term. There is no economic reasoning or theoretical justification for this assumption. Moreover, domestic and international economic policies definitely influence the production behaviour of farms but not all farms are equally influenced by these policies. Therefore, different levels of output may be obtained by different farms, albeit using the same set of inputs. Hence, the conventional varying intercept and fixed slope stochastic frontier approach may not produce reliable efficiency estimates and lead to misleading policy implications. Therefore, further empirical studies with appropriate data and methodology are warranted to examine the impact of liberalization reform on the productive performance of the agriculture sector of Bangladesh.

The next section explains the policy regimes and performance of agriculture sector of Bangladesh before and after reform. Following Hildreth-Houck (1968), Swamy (1971) and Kalirajan and Obwona (1994) analytical framework is presented in section 3. Data sources and variable construction are given in section 4 and in an appendix to the paper followed by model specification and empirical analysis. While the sources of efficiency differentials are discussed in section 5 , conclusions and policy implications are provided in the final section.

\section{Market-Oriented Policy Reform and Agricultural Performance}

Following independence in 1971, Bangladesh pursued an inward looking development strategy with excessive government interventions in almost all economic activities including agriculture. With the ambitious plan of socialist type of agriculture, cooperative farming was encouraged and the procurement and distribution of seed, fertilizers, pesticides and all sorts of agricultural equipments was controlled by the government parastatal -Bangladesh Agricultural Development Corporation (BADC). A series of measures, quantitative restrictions, highly differentiated tariffs rates (0 to 400 per cent), and huge subsidy along with overvalued exchange rate were put in place to protect domestic farms from competition. This protective environment was reinforced by domestic market policy interventions in the form of credit ceiling, arbitrary licensing 
and price controls. These policies did not result of sustained increase of production and productive efficiency rather the gap between demand for and supply of agricultural output has been widened over the years. Finding a way out of this crisis in the 1980s, government pursued policy shift from the state intervention to more market-oriented polices that has translated into sectoral policies, which supported macroeconomic liberalization. Major reforms in agricultural policy included liberalization of input market, shrinking the role of government agency in input distribution, reduction of subsidies in agricultural inputs, liberalization of output markets with producers' price incentive, gradual elimination and narrowing down the public food grain distribution system, price stabilization through open tender procurement policy and allowing private sector in food grain import. While summary of the phases of overall liberalization programs was given in the Appendix Table A1 the details of liberalization in agriculture sector are discussed below.

\section{Liberalization of Agricultural Input Market}

The principal inputs in agriculture comprise fertilizers, irrigation and cultivation equipments, pesticides and seeds. Traditionally, BADC has the sole responsibilities of procuring and distributing agricultural inputs under the conformation to the pricing and related policies formulated by the government over the course of time. But the sustainability of the government interventions towards long term foodgrain availability has been questioned due to the inefficiencies developed in the public management system and the heavy budgetary burden posed by these operations (Ahmed 1995). Realization of such inefficiencies as well as constant pressure of donor agencies government pursued a wide range of policy reforms in order to liberalize the agricultural input market, including privatization of distribution of key agricultural inputs, gradual elimination of subsidies on fertilizer and minor irrigation equipment and improve maintenance of equipment through participation of private sector. Consequently, fertilizer trade is now almost entirely handled by the private sector. Further policies include rationalization and or elimination of import duties on agricultural inputs, such as fertilizer, agricultural equipments and spare parts along with the elimination of government monopoly in fertilizer import, and abolition of standardization requirements, including some other measures in the conditions of availability of inputs to the farmers. There was encouraging response of these liberalization reforms. Private sector participation in input market has risen sharply. Irrigation equipment became cheaper. Different varieties of seeds and fertilizer were 
available to the farmers and thus, making a way to both extensive and intensive cultivation by increasing irrigated area and use of fertilizer.

\section{Liberalization of Agricultural Output Market}

Public policies on agricultural output market are mostly limited to foodgrains and it was heavily intervened by the government since independence. Any kind of distribution and import was the sole responsibility of the state. However, under the liberalization reforms many changes have been initiated to rely more on the market mechanism in the output market. Until the mid 1980s, minimum price programme was the cornerstone of the policy. However, government has rapidly phased out of minimum prices, dismantled the ration system (statutory rationing and rural rationing), privatized and narrowed down the public foodgrain distribution, lifted restrictions and encouraged private sector participation in international trade and drastically reduced its presence in food grain markets with the aim of ensuring foodgrain availability and long-term food security. This reform of abolishing/ shrinking public monopoly on foodgrain trade has important effect in narrowing the gap between domestic and world prices of foodgrain and thus making domestic production and consumption more competitive.

Import duties on key agricultural products have dropped significantly since the late 1980s. By the end of 1980s, almost all non-tariff barriers were replaced by tariff and operative tariff rates on major imports (rice, wheat, pulses and oil seeds) were 15 per cent while the rates for other items such as edible oil, dairy products, vegetables and potatoes varied from 30 to 70 per cent (World Bank 1994). In the early to mid 1990s, operative tariff on foodgrain imports has been reduced to zero percent to cope with the production setback resulting from severe drought and bad weather. However due to the bumper production in consecutive years of 1999 and 2000, an operative tariff of 5\% has been imposed on foodgrain import to provide protection to the domestic producers. Other taxes including, custom duties, sales taxes, development surcharges and license fees have been reduced or eliminated throughout the 1990s in order to encourage private sector imports of other agricultural products such as pulses, oilseeds, edible oil, lentils, etc. The private-sector share in total imports increased from a mere 5 percent in 1978 to over 97 percent by 1992. As of 1995, state trading was abolished for all agricultural commodities except rice, wheat, coarse grain, and oilseeds. Even for these items, no restrictions exist on imports by private traders. Additionally, in 2002 dismantling the frequently adjusted nominal exchange rate government adopted the freely floating exchange rate in order to eliminate the overvaluation of the domestic currency. 
All these policies help creating an open-market economy that makes agricultural inputs (output) readily available for farmers, ensuring food security and guarantees fair commodity prices. A proper assessment of the impact of these market reform policies and trade liberalization on agricultural production requires a sound framework, which is developed in the following section.

\section{Impact of Liberalization on Output Growth}

Bangladesh agriculture achieved a modest growth over the past thee decades. With wide fluctuations, the annual average growth rate is approximately 2.2 per cent during 1972 to 2002 (Statistical Yearbook, several issues). The growth of output barely kept pace with the growth rate (2.45) of population. The striking fact is that the growth of agriculture declined considerably during the first half of the 1990s. This sector grew at the rate of 2.4 per cent during the 1970s and 1.8 per cent during the 1980s but registered very low growth during the first half of the 1990s. The high growth of 1970s might be attributed to the so-called 'green revolution' technology, which allowed the introduction of new high-yielding varieties of rice, wheat and other crops. The deceleration of growth in the 1980s and the early 1990s was mainly due to the loss of agricultural land, regulated market and adverse weather conditions. However, this sector experienced accelerated growth since the second half of the 1990s. In 1997, this sector grew at a rate of 6.4 per cent. Since then rapid acceleration of growth continue and in fact, the annual average growth rate is 4.3 per cent during 1996 to 2002 except the year $1998 .^{3}$ This growth rate surpassed previous growth rate in any period.

Table 1: Performance of Major Agricultural Crops (000 Metric Tons) ${ }^{\mathrm{a}}$

\begin{tabular}{lcccccc}
\hline & \multicolumn{2}{c}{1977} & \multicolumn{2}{c}{1984} & \multicolumn{2}{c}{1997} \\
\cline { 2 - 6 } & $\begin{array}{c}\text { Yield/ } \\
\text { Hectare }\end{array}$ & $\begin{array}{c}\text { Value of } \\
\text { output/ } \\
\text { Hectare }\end{array}$ & $\begin{array}{c}\text { Yield/ } \\
\text { Hectare }\end{array}$ & $\begin{array}{c}\text { Value of } \\
\text { output/ } \\
\text { Hectare }\end{array}$ & $\begin{array}{c}\text { Yield/ } \\
\text { Hectare }\end{array}$ & $\begin{array}{c}\text { Value of } \\
\text { output/ } \\
\text { Hectare }\end{array}$ \\
\hline Rice & 1.17 & 7.85 & 1.37 & 8.55 & 1.78 & 11.75 \\
Wheat & 1.60 & 5.62 & 2.34 & 8.15 & 2.14 & 9.35 \\
Jute & 7.41 & 6.21 & 8.82 & 7.00 & 7.58 & 8.21 \\
Pulses & 0.69 & 4.70 & 0.72 & 4.45 & 0.75 & 5.74 \\
Cereals & 0.68 & 2.67 & 0.63 & 2.87 & 0.97 & 3.76 \\
Oil seeds & 0.76 & 5.70 & 0.99 & 5.90 & 0.85 & 8.25 \\
Sugarcane & 44.30 & 23.60 & 41.75 & 23.52 & 37.89 & 25.15 \\
Potato & 12.75 & 18.30 & 13.42 & 19.44 & 10.09 & 20.46 \\
\hline
\end{tabular}

Source: Bangladesh Census of Agriculture and Livestock, 1977, 1984 and 1997, Bangladesh Bureau of Statistics (BBS), Ministry of Planning, Dhaka, Bangladesh

${ }^{a}$ While output in jute sector measured in terms of thousand bale output in all other crops are in thousand metric tons. Potato Includes sweet potato as well.

\footnotetext{
${ }^{3}$ In 1998, the country was affected by severe flood and the growth of agriculture was nearly zero.
} 
This growth in output is mainly land area expansion because of multiple cropping but the yield growth plays a minor role to this growth. The fact is that farmers in Bangladesh are producing almost on the agricultural land frontier. There is limited or no scope to increase the cultivable land. Therefore, the increasing cropping intensity is the only viable option for land area expansion.

It is seen from Table 1 that some crops such as rice, wheat, pulses and oil seeds experienced modest increase in yield per hectare while others (sugarcane and potatoes) decline from pre-liberalization to post-liberalization period. One recent estimate shows that rice production increased from 11.7 million metric tons in 1974 to 23.1 million tons in 2000, an average annual increase of 3.6 percent while wheat production climbed from 0.11 million metric tons to 1.8 million metric tons in the same period (BBS 2002). Despite the improvement in recent years, yields per hectare, particularly of food crops, are still well below attainable levels (EIU 2000). The target of reform was to improve farm-specific performance through the utilization of the available resources. Although, there is no such link between the liberalization and output growth yet established by solid economic theories there are many international empirical studies examined farmspecific performance before and after reform. However, the findings are inconclusive and the issue remains current subject of empirical investigation.

\section{Analytical Framework}

Productive efficiency is simply defined as the ratio of the actual to maximum possible (potential) output, i.e. $P E=y / y^{*}$; where $P E$ is a measure of productive efficiency, $y$ is

actual output and $y^{*}$ is some measure of potential output. In this equation, the numerator is observable but the denominator is not, which is to be estimated. The seminal work of Farrell (1957) stimulated a large body of both theoretical and empirical research on the measurement of productive efficiency of farms. However, the work of Aigner et al (1977) and Meeusen and van den Broeck (1977) re-ignited the issue and the stochastic frontier models have become the subject of a voluminous literature. Kumbhakar and Lovell (2000) provide an extensive and excellent survey of this literature. In another survey of frontier production function Kalirajan and Shand (1999) pointed out that since the decisions of individual farms are usually independent and their management skills often differ the conventional frontier models seems to be unreasonable in measuring farm-specific productive efficiency. Therefore, this study uses the random coefficient frontier production function to estimate the potential output and thereby, productive efficiency of farms. 
Let the production function parameters describing the production technology be random. Assuming Cobb-Douglas technology, the random coefficient frontier production function can be written as:

$$
\ln y_{i}=\beta_{1 i}+\sum_{j=1}^{k} \beta_{i j} \ln x_{i j} \quad i=1,2,3, \cdots \cdots \cdots \cdot n
$$

where $y$ refers to output level of ith farms and $x$ 's are inputs used by ith farm. $\beta_{i j}$ refers to the actual response of the output to the method of application of the kth input by the ith farm. The above model requires $n K+n$ coefficients to be estimated with the help of only $n$ observations.

Since intercepts and slope coefficients vary across farms around their mean values:

$$
\beta_{i j}=\bar{\beta}_{j}+u_{i j} \text { and } \quad \beta_{1 i}=\bar{\beta}_{1}+v_{i}
$$

where $\bar{\beta}_{j}$ is the mean response coefficient of output with respect to $j$ th input and $v_{i}$ is usual random disturbance term. However, $u_{i j}$ is a crucial variable in this study, as it captures the institutional and organizational changes due to market reform and trade liberalization in the country, which govern the farms' output (Maddala 1977). Therefore, if the relation in Equation (1) is obtained by the maximization behaviour of farms, then it is not appropriate to include $u_{i j}$ additively in Equation (1). Rather, it is appropriate to include $u_{i j}$ as a determining variable for the parameters of the model as in Equation (2). This is one of the strong arguments in favour of applying this model in analysing the performance of production units. $v_{i}$ 's are random disturbance terms which satisfy all the classical assumptions. In addition to the classical assumptions, the following assumptions are also made: $E\left(\beta_{i j}\right)=\bar{\beta}_{j} \quad \operatorname{Var}\left(\beta_{i j}\right)=\sigma_{i}^{2}>0$ and $\operatorname{Cov}\left(\beta_{i j}, \beta_{i m}\right)=E\left(u_{i j} u_{i m}\right)=0 \quad j \neq m$. These imply that the random coefficient $\beta_{j}$ s are independently and identically distributed with fixed mean $\bar{\beta}_{j}$ and variance $\sigma_{u_{j}}^{2}$. Combining equation (1) and (2)

$$
\begin{array}{r}
\ln y_{i}=\bar{\beta}_{1}+\sum_{j=1}^{k}\left(\bar{\beta}_{j}+u_{i j}\right) \ln x_{i j}+v_{i} \\
\text { or } \ln y_{i}=\bar{\beta}_{1}+\sum_{j=1}^{k} \bar{\beta}_{j} \ln x_{i j}+w
\end{array}
$$

where $w$ is a composite disturbance term which has mean zero and variance $E\left(w w^{\prime}\right)=\sigma_{v}^{2} I+\sum_{j=2}^{k} \sigma_{u_{j}}^{2}\left(\ln x_{i j}\right)^{2}$. 
So, it is apparent that the error structure of the above model violates the basic assumptions of constant variance of the linear regression model. The Hildreth-Houck random coefficient model belongs to the class of heteroscedastic error models, where error variances are proportional to the squares of a set of exogenous variables $x$. So the random coefficient regression model reduces to a model with fixed coefficients, but with heteroscedastic variances. This heteroscedasticity will remain, even if $\sigma_{j}^{2}=\sigma^{2}$ values for all $j$ values so long as the square of the explanatory variables is present. Since the above model is heteroscedastic, the ordinary least squares (OLS) method yields unbiased and consistent but inefficient estimates of mean response coefficients. Therefore, the mean response coefficients $\bar{\beta}_{j} \mathrm{~s}$, the variances variance $\sigma_{j}^{2}$ and the individual response coefficients $\beta_{j}$ can be estimated by following the iterative Generalized Least Square (GLS) approach as described in Griffiths (1972).

The assumptions underlying the above model (3) are as follows. The maximum possible output stems from two sources. Firstly, the efficient use of each input contributes individually to the potential output, and can be measured by the magnitude of the varying random slope coefficients ( $\beta$ coefficients). Secondly, when all the inputs are used efficiently, then it may produce a combined contribution over and above the individual contributions. This latter 'lump sum' contribution, if any, can be measured by the varying random intercept term. The highest magnitude of each response coefficient, and the intercept term from the production coefficients of equation (3), constitute the production coefficients of the frontier function, showing the maximum possible output.

To elaborate, let $\beta_{1}^{*}, \beta_{2}^{*}, \beta_{3}^{*}, \cdots \cdots \cdots \beta_{K}^{*}$ be the estimates of the parameters of the frontier production function yielding the potential output. The frontier coefficients $\beta^{*} \mathrm{~s}$ are chosen in such a way to reflect the condition that represent the production responses of following the 'best practice' techniques. These are obtained from among the individual response coefficients, which vary across observation as follows:

$$
\beta_{j}^{*}=\max \left\{\beta_{i j}\right\} \quad i=1,2,3, \cdots \mathrm{n} \text { and } j=1,2,3, \cdots \mathrm{K}
$$

The key points to note here are first, that these frontier coefficients need not necessarily correspond to the response coefficients for any single individual observation. They may represent the best combination of response coefficients derived from different individual observations. For example, $\beta_{1}^{*}$ may come from the $7^{\text {th }}$ observation while $\beta_{4}^{*}$ may come from the $12^{\text {th }}$ observation, and so on. This supports the earlier assertion that 
not all farms use each input efficiently. Second, the possibility of obtaining all $\beta_{j}^{*}$ 's from a single observation cannot be ruled out. Human capital theory literature argues that a farm which uses some inputs efficiently may also use all inputs efficiently (Kalirajan and Obwona 1994). When the response coefficients are selected by using (4), then the potential output for the ith farm can be worked out as:

$$
y_{i}^{*}=\sum \beta_{j}^{*} \ln x_{i j}
$$

where $x_{i j}$ 's refer to actual levels of inputs used by the ith farm. Subsequently, a measure of productive efficiency $(P E)$ can be defined as follows:

$$
P E_{i}=\frac{\text { actual output }}{\text { potential output }}=\frac{y_{i}}{y_{i}^{*}}
$$

$P E$ varies between 0 to 1 . Thus, the varying coefficient regression model approach provides a realistic approach for estimating $P E$ over a large number of farms using cross-section data.

\section{Data, Model Specification and Empirical Results}

Data

The data for this study came from the Agricultural Census conducted by the Bangladesh Bureau of Statistics (BBS). So far, BBS conducted three censuses with the latest one in 1997. The previous agricultural censuses carried out in 1977 and 1984. These censuses collected household level information on agricultural production under single management. So these three periods serve as pre-reform, transition and after reform respectively. Household level data were chosen from five regions, namely, Comilla, Dinajpur, Noakhali, Rajshahi and Sylhet, where agricultural crops are cultivated extensively. ${ }^{4}$ The data quality has been examined comparing with some other independent survey data along with reviewing the comments of the researchers of the country. ${ }^{5}$ Initially, households with less than 0.5 hectares were removed from the BBS supplied raw data and 1000 households were randomly selected from the above regions. ${ }^{6}$ Then, households with either incomplete or where the sum of various components are found to be inconsistent with reported aggregates on the basis of usual

\footnotetext{
${ }^{4}$ There are not much variations in the annual rainfall intensity or soil types in these regions. Lands are equally fertile for crop production.

${ }^{5}$ Pray (1980) argued that Bangladesh Bureau of Statistics (BBS) tries to maintain the acceptable quality of agricultural statistics in the post-green revolution period given its sensitivity to food import. More on the data quality issues can be found in Boyce (1987) and Alauddin and Tisdell (1987).

${ }^{6}$ About 32 percent of rural households owned no land or fewer than 0.2 hectares of cultivable land. The average farm household cultivated 4 hectares of land, but half of all farms are around 1 hectare in 1997 (Bangladesh Agricultural Census 1997).
} 
accounting principles, are left out from the analysis. Finally, 452 households were chosen for the analysis. The sample includes both traditional and modern variety used farms and comprises 100 households from Comilla, 95 from Dinajpur, 82 from Noakhali, 90 from Rajshahi, and 85 from Sylhet regions. The aggregate value of output and five other variables such as land $(T)$, labour $(L)$, capital $(K)$, fertilizer $(F)$, and pesticides $(P)$ are taken for estimating production function. However, the land area is used here in physical term, hectare. While the details of the construction of these variables are given in the appendix the summary statistics of these variables are presented below in Table 2.

Table 2: Summary Statistics of the Selected Variables (per household)

\begin{tabular}{lccccccccc}
\hline & \multicolumn{3}{c}{1977} & \multicolumn{3}{c}{1984} & \multicolumn{3}{c}{1997} \\
\cline { 2 - 9 } Variables & Min & Mean & Max & Min & Mean & Max & Min & Mean & Max \\
\hline Output (Y) & 15.24 & 23.65 & 29.40 & 18.05 & 30.80 & 37.35 & 20.65 & 29.55 & 40.44 \\
Land (T) & 1.50 & 4.75 & 14.40 & 1.35 & 5.15 & 12.50 & 1.60 & 4.55 & 12.10 \\
Labour (L) & 1.51 & 5.55 & 7.85 & 2.90 & 6.70 & 10.55 & 3.25 & 8.15 & 12.40 \\
Capital (K) & 5.56 & 8.62 & 10.10 & 6.25 & 9.85 & 13.45 & 7.75 & 10.56 & 15.05 \\
Fertilizer (F) & 0.82 & 2.15 & 3.50 & 1.05 & 2.65 & 4.76 & 1.85 & 3.27 & 5.64 \\
Pesticides (P) & 0.31 & 1.87 & 2.22 & 0.87 & 2.10 & 3.76 & 1.50 & 3.10 & 4.86 \\
\hline
\end{tabular}

Source: Bangladesh Census of Agriculture and Livestock, 1977, 1984 and 1997, Bangladesh Bureau of Statistics (BBS), Ministry of Planning, Dhaka, Bangladesh.

Note: All variables are measured in ' 000 ' Taka except land, which is measured in hectare. Official exchange rate is US\$1 $=42.70$ Taka in 1997 .

Model Specification and the Estimates of Productive efficiency

The reliability of efficiency estimates hinges crucially on the specification of the model. The Cobb-Douglas functional form has been extensively used in stochastic frontier production function analysis as this affords maximum flexibility in dealing with data imperfections (Tybout 1990). Although it is argued that the Translog production function is a more general type of production function, it may not provide efficient estimates, because collinearity among the explanatory variables can not be avoided. It is therefore not surprising that recent surveys of empirical applications of frontier production functions by Kumbhakar and Lovell (2000) revealed that the Cobb-Douglas technology specifications still continue to dominate. Nevertheless, the Translog and the Cobb-Douglas specifications for annual crop data are sequentially tested by using the generalized likelihood ratio (LR) test as an important decision-making tool when 
theoretical considerations do not suggest correct functional specifications. Statistical results support the Cobb-Douglas functional form in each case. ${ }^{7}$

Accordingly, the following the Cobb-Douglas production function is used to estimate the maximum possible output of individual farm and the resulting estimates are then used to estimate farm-specific productive efficiency:

$$
\ln y_{i}=\ln \alpha_{i}+\sum_{k=1}^{5} \beta_{k} \ln x_{k i} \quad i=1,2,3, \cdots \cdots \cdots 452
$$

where $y$ refers to gross value of crops and $x$ 's are inputs, such as land, labour ,capital, fertilizer and pesticides respectively.

The Breusch-Pagan's $L M$ test was used to test the randomness of coefficients of the specified model. ${ }^{8}$ The results rejected individual heteroscedasticity in favour of vector heteroscedasticity, lending support to the random coefficient model specification. However, this test does not provide any indication of the exact form of randomness of coefficients. Therefore, this study used one class of random coefficient model, in which it is assumed that the coefficients vary unsystematically, i.e. the response to a change in one explanatory variable is different for different observations. The computer program TERAN ${ }^{9}$ was used to estimate the unconstrained variance-covariance matrix of the random coefficients (Schwallie, 1982) to obtain the GLS (Generalised Least Squares) mean estimator and individual response coefficients (Griffiths, 1972). These estimators were then used to estimate the empirical model (8) for household level data of the selected regions of Bangladesh.

7 The formal test was conducted to determine the suitable functional form under the null hypothesis is that the coefficients of the cross and squared terms in the translog function taken together are not significantly different from zero. The calculated $\chi_{(n, \alpha)}^{2}$ statistics are as follows:

$\begin{array}{lllll}\text { Regions } & \text { Log Likelihood } & \underline{1977} & \underline{1984} & \underline{1997} \\ \text { Comilla } & 720.8612 & 2.3412 & 2.3333 & 1.2768 \\ \text { Dinajpur } & 653.3417 & 1.8861 & 1.1562 & 2.7753 \\ \text { Noakhali } & 701.2445 & 1.5642 & 2.7651 & 1.8874 \\ \text { Rajshahi } & 678.0241 & 1.7893 & 1.9882 & 1.6754 \\ \text { Sylhet } & 720.5632 & 2.6742 & 2.5692 & 2.1162\end{array}$

8 The calculated Chi-Square $\left(\chi_{(k-1,0.95)}^{2}\right)$ statistics for parameter variation:

$\begin{array}{llll}\text { Regions } & \underline{1977} & \underline{1984} & \underline{1997} \\ \text { Comilla } & 22.15 & 18.91 & 26.11 \\ \text { Dinajpur } & 18.04 & 25.72 & 27.55 \\ \text { Noakhali } & 35.33 & 33.07 & 32.82 \\ \text { Rajshahi } & 42.12 & 55.42 & 45.09 \\ \text { Sylhet } & 21.55 & 27.35 & 28.67\end{array}$

9 TERAN was developed in the Division of Economics, Research School of Pacific and Asian Studies, The Australian National University. The program, written in Fortran 77, can be compiled and run on UNIX and VAX based mainframe computers and on IBM PC/AT with 640K memory using Microsoft FORTRAN V.5 and LAHEY FORTRAN V.5. 
The iterated GLS estimates of Equation (7) for each region are calculated separately as well as total sample together. Estimates of the total sample are given in Tables 3 while the region wise estimates can be obtained upon request. Recalling Equation (2), the moments of coefficients, rather than the coefficients themselves, are fixed parameters, i.e. $\bar{\beta}_{j}$ 's are constant across farms in a region but $\beta_{j}$ 's are not. The approximate Aitken estimates of means of these coefficients and their asymptotic standard errors for the total sample are given in Table 3. The year 1977 is in the pre-reform period, 1984 is in the transition period and 1997 is in the post-reform period (the most recent year for which data are available). The range of actual response coefficients and frontier coefficients are also presented in this Table. These parameters help in estimating farmspecific productive efficiency. Empirical estimates facilitate comparisons of farmspecific productive performances among these periods. This further validates the importance of the varying coefficients frontier approach over the conventional constantslope but varying intercept production frontiers in estimating farm-specific productive efficiency measures.

Table 3: The GLS Estimates of Actual, Mean Response and Frontier Coefficients

\begin{tabular}{|c|c|c|c|c|c|c|c|c|c|}
\hline \multirow{2}{*}{$\begin{array}{l}\text { Years/ } \\
\text { Variables }\end{array}$} & \multicolumn{3}{|c|}{1977} & \multicolumn{3}{|c|}{1984} & \multicolumn{2}{|r|}{1997} & \multirow[b]{2}{*}{$F C$} \\
\hline & RARC. & $M R C$ & $F C$ & RARC. & MRC & $F C$ & RARC & MRC & \\
\hline$C$ & $0.03-0.08$ & $\begin{array}{c}0.06 \\
(0.02)\end{array}$ & 0.08 & $0.02-0.07$ & $\begin{array}{c}0.05 \\
(0.01)\end{array}$ & 0.07 & 0.04-0.08 & $\begin{array}{c}0.06 \\
(0.02)\end{array}$ & 0.08 \\
\hline$L$ & $0.21-0.30$ & $\begin{array}{c}0.24 \\
(0.09)\end{array}$ & 0.30 & $0.22-0.32$ & $\begin{array}{c}0.27 \\
(0.10)\end{array}$ & 0.32 & $0.23-0.33$ & $\begin{array}{c}0.28 \\
(0.11)\end{array}$ & 0.33 \\
\hline$K$ & $0.16-0.27$ & $\begin{array}{c}0.21 \\
(0.04)\end{array}$ & 0.27 & $0.15-0.26$ & $\begin{array}{l}0.20 \\
(.04)\end{array}$ & 0.26 & $0.17-0.28$ & $\begin{array}{l}0.25 \\
(0.08)\end{array}$ & 0.28 \\
\hline$T$ & $0.32-0.52$ & $\begin{array}{c}0.42 \\
(0.13)\end{array}$ & 0.52 & $0.38-0.47$ & $\begin{array}{c}0.42 \\
(0.15)\end{array}$ & 0.47 & $0.41-0.55$ & $\begin{array}{l}0.49 \\
(0.09\end{array}$ & 0.55 \\
\hline$F$ & $0.17-0.28$ & $\begin{array}{c}0.23 \\
(0.05)\end{array}$ & 0.28 & $0.18-0.27$ & $\begin{array}{c}0.25 \\
(0.07)\end{array}$ & 0.27 & $0.20-0.25$ & $\begin{array}{c}0.18 \\
(0.04)\end{array}$ & 0.25 \\
\hline$P$ & $0.15-0.24$ & $\begin{array}{c}0.18 \\
(0.04)\end{array}$ & 0.24 & $0.12-0.22$ & $\begin{array}{c}0.16 \\
(0.03)\end{array}$ & 0.22 & $0.16-0.24$ & $\begin{array}{l}0.20 \\
(0.5)\end{array}$ & 0.24 \\
\hline$\sigma^{2}$ & 0.08 & & & 0.10 & & & 0.12 & & \\
\hline
\end{tabular}

Source: Estimated by the computer program TERAN. Figures in parentheses are standard errors. Note: $R A R C=$ Range of actual response coefficients, $M R C=$ Mean response coefficients, $F C=$ Frontier coefficients.

It is apparent from Table 3 that all the mean response coefficients are significant at the 5 per cent level and signs and magnitudes of these variables are in conformity with theoretical expectations. The ranges of the actual response coefficients are quite substantial because of the large variation in the error component. This suggests the presence of randomness in the response coefficients. From this randomness among the actual response coefficients, the important information emerges that sample farmers exercised different technical practices in crop production. Moreover, contributions of 
inputs to output in the production process differ from farm to farm. Consequently, farm performance measures (say, productive efficiency) which are based on production frontiers derived from farm-specific constant slope, but varying intercept production functions, necessarily lead to misleading results. Since, such models fail to take into account individual input responses that vary among individual inputs in modelling farm performance. Thus, these estimates validate the use of the random coefficient production frontier. The estimates of frontier coefficients, presented in the columns 4, 7 and 10 of Table 3 indicate the maximum possible contribution of inputs to output when farms are operating on their frontiers and are following 'best practice techniques' of given technologies.

Following Equation (6) obtained productive efficiency estimates are presented in Table 4. There are wide variations in productive efficiency across farms. Although some farms are producing close to the production frontier, most farms are not. Approximately 40 per cent of sample farms are producing below 55 per cent of productive efficiency whereas only 6 to 9 per cent of sample farms are producing at 86 to 100 per cent efficiency level. This is why mean level efficiency estimates are somewhere between 50 to 65 per cent. It is seen from Table 4 that farms gained only moderate increases in efficiency in the post reform period. That is approximately 9 per cent of sample farms are now producing close to frontier while 34 per cent of farms are producing below 55 per cent of productive efficiency.

Table 4: Farm-Specific Productive Efficiency Estimates (1977-1997)

\begin{tabular}{|c|c|c|c|}
\hline Ranges of & 1977 & 1984 & 1997 \\
\hline $\begin{array}{l}\text { Efficiency } \\
\text { indices }\end{array}$ & No. farm & No. farm & No. farm \\
\hline $0.350-0.455$ & $66(0.15)$ & $68(0.15)$ & $45(0.10)$ \\
\hline $0.460-0.555$ & $130(0.29)$ & $126(0.28)$ & $110(0.24)$ \\
\hline $0.560-0.655$ & $136(0.30)$ & $133(0.29)$ & $140(0.31)$ \\
\hline $0.660-0.755$ & $51(0.11)$ & $53(0.12)$ & $63(0.14)$ \\
\hline $0.760-0.855$ & 37 (0.08) & $44(0.10)$ & $55(0.11)$ \\
\hline $0.860-0.955$ & $25(0.06)$ & $20(0.04)$ & $25(0.06)$ \\
\hline $0.960-1.00$ & $7(0.02)$ & $8(0.02)$ & $14(0.03)$ \\
\hline Minimum & 0.354 & 0.412 & 0.454 \\
\hline Mean & 0.562 & 0.601 & 0.642 \\
\hline Maximum & 1.000 & 1.000 & 1.000 \\
\hline SD & 0.152 & 0.139 & 0.157 \\
\hline
\end{tabular}

Source: Calculated using the household data from the Bangladesh Census of Agriculture and Livestock, 1977, 1984 and 1997, Bangladesh Bureau of Statistics (BBS), Ministry of Planning, Dhaka, Bangladesh.

Note: S.D.=Standard Deviation. Numbers in parentheses show the percentage of sample farms. 
The average productive efficiency estimates of all regions are approximately 56, 60 and 64 per cent in the pre reform (1977), transition (1984) and post reform (1997) periods respectively. That is the average efficiency increased by 8 percentage point from prereform to post reform period. This increased efficiency may partly be attributable to market deregulation and trade policy reform and partly to other factors such as good weather, etc. It is likely that the recent liberalization reform removed various distortions from the agricultural input and output markets that enhanced farmers' accessibility to new seed varieties, modern technology, market information, and education, which benefited farmers by improving their production efficiency in crop production. However, there is substantial inefficiency still remain at the household level farming in agricultural production. Most farms are performing below the frontier and approximately 20 to 35 per cent output are lost owing to inefficiency in production. The main implication of these results is that farms could reduce their inputs by considerable amounts without reducing their output, simply by improving efficiency in production. In other words, farms could easily increase output without further increase in inputs. In fact, in a recent study conducted by the Ministry of Agriculture (MOA) shows that there is a huge yield gap between actual and potential output at the farm level. The potential yield of rice (modern variety) is around 6 tons per hectare against 2.78 tons of actual output (MOA 2003). The overall production will increase by 15 to 20 per cent if the yield gap is minimized.

Although the above findings of this study are not directly comparable to those of earlier studies because of differences in data used, reference period and farm structure, however, they give some indications about the past performance of farms that are important for policy purposes. The above findings conform to those of Sharif and Dar (1996), Wadud and White (2000) and Coelli et al (2002) though they used survey data on rice production only, covering one or two or some villages of a particular region of the country. Their average farm-specific-efficiency estimates vary from 50 to 80 per cent depending on the different variety of rice cultivation. Only recently Rahman (2003) found that the average profit efficiency of modern variety used rice farmers is 0.77 but individual efficiency estimates widely varied across farms. It is interesting to note that the findings of the current study do not differ remarkably, even though all the above studies used only rice production data. None of these studies incorporated the socioeconomic and institutional changes due to market and trade reforms in the analysis. Some international studies (Kompas, 2002; Haghiri et al., 2004; Iraizoz et al., 2005) reported that liberalization led to increase productive efficiency at the farm level while 
others (Jayne et al., 2002; Dembele and Staatz, 2002; Dercon, 2001) found little or no improvement in farm-specific efficiency due to reform. However, these findings have to consider with caution as these studies either used conventional econometric techniques or aggregate data or even farm level data from an economy when the liberalization process was incomplete. In fact, there is one study by Huang and Kalirajan (1997) applied the random coefficient model to Chinese agricultural farm household data over the 1993-95 periods and reported that the economic liberalization significantly improved farms' efficiency.

One of the main objectives of recent economic reform was to increase the productive efficiency at the farm level so that output growth would take place with the existing inputs and technology. The above findings i.e. the moderate increase in farm level productive efficiency ( 8 percentage point) cannot directly be attributed to the liberalization programs but it can be argued that liberalization along with other factors contributed to this improvement. This is true that the actual gains in improved productive efficiency depend upon largely on the behavioural reaction of farms to liberalization programs. However, insufficient funds, poor infrastructure, inadequate research, training and education of farmers hamper the ability of many farmers to respond efficiently to market signals. These factors will be examined in the next section.

\section{Factors Affecting the Productive efficiency of Farms}

Productive efficiency scores obtained from the production frontier approach have a very limited utility for policy and management purposes if empirical studies do not investigate the factors affecting efficiency. The productive efficiency of agricultural farms is not only affected by the farm specific attributes but also by the country's domestic and international (trade \& exchange rate) policies. The later has become very important in the wake of deregulation and liberalization. The summary statistics of these variables appear in Table 5.

Drawing on the earlier theoretical and empirical studies the following equation is specified:

$$
P E_{i t}=f\left(F S Z_{i t}, T N C I_{i t}, C D I_{i t}, E D U_{i t}, I N F I_{i t}, E R A_{i t}, N A G I_{i t}, D X T S_{i t}\right)+u_{i t}
$$

where PE stands for farm-specific productive efficiency indices, FSZ for size of farm (in terms of hectare), TNCI for tenancy (proportion of rented-in land cultivated by the farm household), CDI for crop diversification index (For each farm, a 'Herfindahl' production diversification index is computed, using the shares of each crop output in place of the market shares of firm sales that is used when calculating the conventional 
Herfindahl index in Industrial Organization (IO) studies. The Herfindahl index achieves its maximum value of one in the case of single crop, and declines with an increase in the number of crops), EDU for the average level of education (average years of schooling by the household members), INFI for the index of underdevelopment infrastructure (constructed by following Ahmed and Hossain (1990) using the cost of accessing various facilities such as storage, market, bank, extension services, etc. A total of 12 elements are considered to construct this index. A high value of this index means very backward infrastructure), ERA for the effective rate of assistance, which incorporates both trade and domestic assistance policies that directly affect the prices of factors, material inputs, products, the assistance in the form of price and quantity controls, import bans, and subsidies (constructed by following Rahman 1992), NAGI for nonagricultural income share (proportion of household income received from nonagricultural sources), DXTS for extension services received by household farms (dummy variable to measure the influence of extension services on productive efficiency such as value 1 indicates if the farm household had had services from the extension offices or zero otherwise) and $u_{i t}$ for white noise error term. Subscripts $i$ refer to farm household and $t$ to years.

Table 5: Factors Influencing Productive efficiency

\begin{tabular}{lccc}
\hline Variables & 1977 & 1984 & 1997 \\
\hline Farm Size (FSZ: hectare) & 4.75 & 5.15 & 4.55 \\
Crop Diversification Index (CDI: \%) & 0.076 & 0.62 & 0.45 \\
Tenancy (TNCI: \%) & 27.5 & 35.7 & 38.8 \\
Level of Education (EDU: years) & 2 & 2.5 & 3.5 \\
Infrastructural Index (INFI: number) & 22.45 & 25.76 & 35.54 \\
Non-agricultural Income (NAGI: \%) & 12.6 & 17.2 & 20.1 \\
Effective Rate of Assistance (ERA: number) & 0.232 & 0.181 & 0.163 \\
Extension Services (DXTS: \%) & 5.35 & 8.40 & 10.25 \\
\hline
\end{tabular}

Note: Mean values of all variables are presented in the table.

Source: Calculated by following Ahmed and Hossain (1990) and Rahman (1992) using the household data from the Bangladesh Census of Agriculture and Livestock, 1977, 1984 and 1997, Bangladesh Bureau of Statistics (BBS).

Given the socio-economic and production conditions in Bangladesh it is expected that the variables such as FSZ, TNCI, CDI, and ERA influence the farm-specific productive efficiency negatively while the other variables such as EDU, INFI, NAGI and DXTS positively. To estimate the above model three approaches are used: pooled regressions 
with no controls for farm or time effects, fixed effects and random effects models. The results obtained using these estimators, are presented in Table 6. The results are generally consistent with a priori expectations as outlined above. It is apparent from Table 6 that the variable FSZ negatively influence farm level efficiency although economic theory give us very little guidance about the relationship. This implies that the larger the farm size the lower is the output and vice versa. The variable is statistically significant at one percent level in both the fixed effects and the random effects models. This result is not surprising given that labour-intensive crops represent a large share of the overall agricultural production in Bangladesh. Lack of adequate funding for mechanization labour intensive farming remains most profitable to farmers. Thus, labour-intensive agriculture has achieved steady increase in food grain production over time (Ministry of Agriculture 2003). Small farms are mostly family based and each worker work with long hours. It may also be argued that small farms are flexible in responding to changes in technology, prompt in choosing appropriate inputs and utilize the existing resources fully. Huang and Kalirajan (1997) reported similar results in case of Chinese agriculture while Rezitis et al (2002) and Latruffe et al (2004) reported opposite results in cases of Greek and Polish agriculture respectively. However, Haghiri et al (2004) and Wu et al (2003) reported that productive efficiency is independent of farm size.

The negative coefficient of the tenancy variable (TNCI) conforms a priori expectations that farms with a large proportion of rented land would show low efficiency, because the principal-agent relationship between the land owners and the shareholders that deter productive efficiency. Such shareholder farmers have little incentives to invest for land improvement. However, the coefficient is not statistically significant. Crop diversification index $(C D I)$ as expected influences $P E$ negatively and its coefficient is not statistically significant as well. This means that the lower the diversification (the high value of $C D I$ ) the lower is the productive efficiency. This is true farmers are still producing one or two crops throughout the year even after the policy shift in agriculture since the late 1970 s.

The positive sign of the education variable (EDU) indicates that the higher the level of farmer's education the more efficient is the agricultural farm. This variable reflects household's human capital stock and individual's ability to understand modern cultivation. On average, one more year of formal education improve productive efficiency by 0.045 percent. However, the variable is not statistically significant. Since the country's education level is still very low such poor impact of education on productive 
efficiency is not unexpected. Rahman (2003) and Wadud and White (2000) also reported similar results in their studies on Bangladesh. The variable INFI positively influence the farmers' efficiency. This implies that good infrastructure such as road \& transportation, easy access to banks, storage, market, etc. increase farmers’ ability in production. This variable appears to be statistically significant at 5 percent level. This finding is consistent with the country's enormous development in road transportation and other communication, banking, storage facilities, etc. since the early 1980s right after the introduction of the structural adjustment policies.

Table 6: Factors Influencing Farm Specific Productive efficiency

\begin{tabular}{lccc}
\hline Variables & $\begin{array}{c}\text { Pooled Model } \\
(\mathbf{1})\end{array}$ & $\begin{array}{c}\text { FE Model } \\
\mathbf{( 2 )}\end{array}$ & $\begin{array}{c}\text { RE Model } \\
\mathbf{( 3 )}\end{array}$ \\
\hline \multirow{2}{*}{ INTERCEPT } & $0.167^{* *}$ & 0.086 & $0.114^{*}$ \\
& $(0.045)$ & $(0.038)$ & $(0.035)$ \\
FSZ & $-0.134^{* * *}$ & $-0.125^{* * *}$ & $-0.121^{* * *}$ \\
& $(0.032)$ & $(0.021)$ & $(0.015)$ \\
TNCI & -0.142 & -0.163 & -0.172 \\
& $(0.087)$ & $(0.082)$ & $(0.091)$ \\
CDI & -0.024 & -0.042 & -0.047 \\
& $(0.037)$ & $(0.028)$ & $(0.025)$ \\
EDU & 0.043 & 0.045 & 0.057 \\
& $(0.034)$ & $(0.033)$ & $(0.030)$ \\
INFI & $0.095^{* *}$ & $0.102^{* *}$ & $0.105^{* *}$ \\
& $(0.028)$ & $(0.032)$ & $(0.027)$ \\
NAGI & $0.121^{* *}$ & $0.124 * *$ & $0.129 * *$ \\
& $(0.046)$ & $(0.042)$ & $(0.038)$ \\
ERA & $-0.127^{* *}$ & $-0.132^{* *}$ & $-0.135^{* *}$ \\
& $(0.042)$ & $(0.047)$ & $(0.040)$ \\
DXTS & 0.051 & 0.047 & 0.032 \\
& $(0.043)$ & $(0.035)$ & $(0.027)$ \\
$\mathrm{R}^{2}$ & & & 0.51 \\
No. of farms & 0.35 & 0.47 & 452 \\
Sample Size & 452 & 452 & 1356 \\
\hline
\end{tabular}

Note: At the outset both an $F$ and Hausman tests are used to test whether individual farm effects are significant as well as whether the regressors are correlated with the individual effects. The results $\left(F=1.42\right.$ and $\left.\chi^{2}=25.73\right)$ suggested for the fixed farm effects specification but rejected the exogeneity in the random effects model. Therefore, the focus of this study is on the fixed effect estimates; however, for comparison random effects estimates are also presented. Figures in the parentheses are standard errors. The asterisks $* * *, * *$, and $*$ indicate significance at 1, 5 and 10 per cent level, respectively. Farm-specific and year dummies used in estimating model 2 are not shown.

From Table 6, it is also seen that the variable NAGI (proportion of household income received from non-agricultural sources) influences farm specific efficiency positively. This implies that the higher the proportion of income received by the farmer household from non-agricultural sources the higher will be the farms' output. This is true that 
farmers can act quickly to change inputs, technology, insecticides and pesticides in time if they have more income from non-agricultural sources. The coefficient of this variable is significantly different from zero at a 5 percent level of significance. This result is consistent with the findings of Liu and Zhuang (2000) who reported that farmers' offfarm income positively influence productive efficiency in China. The negative coefficient of ERA indicates that the anti-agriculture bias of the relevant government policies largely contributed to the reduction of farm level efficiency and thereby slow down of the over all agricultural growth. The coefficient is statistically significant at the 5 percent level of significance. Such an outcome might be the result of the failure of liberalization to remove anti-agriculture bias policies such as tariffs, NTBs, and differential assistance to farmers and other producers, etc. The extension services dummy (DXTS) exerted an insignificant influence, although its coefficient has the expected positive sign in all models. The above findings appear to be consistent with the agrarian structure and the country’s agricultural practices.

\section{Conclusion and Policy Implications}

This study highlighted the major policy changes in relation to agriculture in Bangladesh over the last three decades and their impact on farm level crop production. Farmspecific productive efficiency indices are estimated in the pre-reform (1977), transition (1984) and post reform (1997) periods using the random coefficient frontier production framework following Hildreth-Houck (1968), Swamy (1971) and Kalirajan and Obwon (1994). The empirical results showed that there is wide variability in efficiency across farms and regions of the country and the average farm-specific efficiency increased from 0.56 in 1977 to 0.64 in 1997, i.e. efficiency increased by only 8 percentage point from the pre- to post- reform period. This increased efficiency at the farm level may partly be attributable to market and trade policy reform. It is likely that the recent liberalization reform removed various distortions from the agricultural input and output markets that enhanced farmers' accessibility to new seed varieties, modern technology, market information, and education that lead to improve farmers' efficiency in crop production. However, substantial inefficiency still remains in Bangladesh agriculture. This implies that there is potential for further increase in output without increasing inputs by simply improving the productive efficiency at the farm level. In the second stage analysis, this study also attempts to identify some influential variables which might be manipulated by government policies to improve farm level productive efficiency. While not all factors are statistically significant, there are some important 
indicators for policy purposes. Government policies should be aimed at encouraging human capital accumulation through formal education and training to farmers and spreading the 'best practice' methods and their benefits to farmers through extension and other related services. Moreover, there is a need for further reform of domestic market and trade policies focusing on institutional changes, tariff and non-tariff barriers in order to develop a competitive environment in agriculture. On the whole, a coherent set of policies has to be more vigorously pursued so that an efficient pattern of production can take firmer root in order to exploit the potential of this sector of the economy. 


\section{Appendix}

Table A1: Summary of Policy Shift in Bangladesh 1972-2002

\begin{tabular}{|c|c|c|c|}
\hline $\begin{array}{l}\text { Reform } \\
\text { Content }\end{array}$ & Phase I (1972-79) & Phase II (1980-90) & Phase III (1991-02) \\
\hline Trade & $\begin{array}{l}\text { Tightly regulated policy } \\
\text { environment with heavy } \\
\text { state controls, severe } \\
\text { trade controls on both } \\
\text { export and import, } \\
\text { including NTBs and } \\
\text { heavy duties, often } \\
\text { prohibitive; fixed } \\
\text { exchanged rate system } \\
\text { with considerable over } \\
\text { valuation. Tariff rate } \\
\text { varied from } 10 \% \text { to } \\
300 \% \text {. }\end{array}$ & $\begin{array}{l}\text { Initial phase of } \\
\text { trade reforms with } \\
\text { some relaxation of } \\
\text { NTBs and tariff } \\
\text { barriers; creation of } \\
\text { enabling 'free } \\
\text { trade' environment } \\
\text { for garments sector } \\
\text { (bonded } \\
\text { warehouses, duty } \\
\text { free inputs, etc.) } \\
\text { pegged the taka to } \\
\text { the currencies of } \\
\text { the nation's major } \\
\text { trading partners. }\end{array}$ & $\begin{array}{l}\text { Substantial } \\
\text { liberalization of trade } \\
\text { and investment, } \\
\text { market orientation, } \\
\text { and opening up with } \\
\text { large reduction in } \\
\text { NTBs and } \\
\text { rationalization of } \\
\text { tariffs; shift from } \\
\text { fixed to moderately } \\
\text { flexible exchange rate } \\
\text { system and unified } \\
\text { the two tired foreign } \\
\text { exchange market. }\end{array}$ \\
\hline $\begin{array}{l}\text { Goods } \\
\text { Sectors }\end{array}$ & $\begin{array}{l}\text { Massive nationalization } \\
\text { of industrial enterprises; } \\
\text { emphasizing cooperative } \\
\text { agricultural farming; } \\
\text { price controls, control of } \\
\text { agriculture inputs and } \\
\text { marketing. }\end{array}$ & $\begin{array}{l}\text { Initial period of } \\
\text { denationalization, } \\
\text { deregulation and } \\
\text { removal of price } \\
\text { controls; significant } \\
\text { liberalization of } \\
\text { agriculture sector - } \\
\text { input and output } \\
\text { markets. }\end{array}$ & $\begin{array}{l}\text { Further progress with } \\
\text { privatization of } \\
\text { manufacturing } \\
\text { enterprises, initiation } \\
\text { of deregulation } \\
\text { measures to improve } \\
\text { the investment } \\
\text { climate for private } \\
\text { enterprises. }\end{array}$ \\
\hline $\begin{array}{l}\text { Services } \\
\text { Sectors }\end{array}$ & $\begin{array}{l}\text { Nationalization of most } \\
\text { services including } \\
\text { banking, infrastructure } \\
\text { and even trading; } \\
\text { administered prices. }\end{array}$ & $\begin{array}{l}\text { Initial period of } \\
\text { encouraging private } \\
\text { sector in banking } \\
\text { and other financial } \\
\text { services; rent and } \\
\text { price control lifted } \\
\text { substantially; state } \\
\text { trading abolished, } \\
\text { with one exception, } \\
\text { TCB, for imports } \\
\text { of sugar, fertilizer } \\
\text { and rice. }\end{array}$ & $\begin{array}{l}\text { Further progress with } \\
\text { policies support } \\
\text { private investment in } \\
\text { banking and } \\
\text { infrastructure; power } \\
\text { generation, } \\
\text { telecommunications, } \\
\text { opened to private } \\
\text { investors. }\end{array}$ \\
\hline
\end{tabular}

Source: Ahmed and Sattar (2003) and author's collection from the Government documents. 


\section{Variable Construction}

Aggregate Output (Y): includes all seasons and varieties of paddy (Aus, Amon and Boro), wheat, jute, sugarcane, potato, pulses, oil seeds and cereals (barley, maize, etc.) produced by each household. According to the census, these crops accounted for more than 90 percent of the total cultivated area by per household, a share that held relatively constant over the years. In the census, output is measured by sales of all these crops in ('000 taka) at farm-gate price. Aggregate value is constructed as the sums of sales plus farm use plus farm household consumption and it is then estimated at constant 1984/85 prices.

Labour (L): includes both hired and family labours engaged in production. Following Shidu and Baanante (1981) total labour expenditures includes the wage paid to the permanent workers plus the imputed cost of the family labours at the wage rate paid to the permanent hired labour.

Land (T): measured as hectares that were under crop cultivation by per household in the year of the census. By following Coelli, et al (2002) it can be argued that this measure of land area allows for changes in cropping intensity.

Capital (K): computed as the sum of costs of animal and mechanical power used in crop production in the census year.

Fertilizer (F): total expenditures on all fertilizer nutrients used in crop production including transportation costs.

Pesticides (P): total expenditures on insecticides, fungicides, weedicides, herbides and similar products, rodenticides and other insecticides used in production. 


\section{References}

Ahmed, R. (1995) Liberalization of input markets in Bangladesh: process, impact and lessons, Agricultural Economics, 12, 115-28.

Ahmed, R., Hossain, M. (1990) Developmental impact of rural infrastructure in Bangladesh, Research report no. 83. International Food Policy Research Institute (IFPRI), Washington, DC.

Ahmed, S. and Sattar, Z. (2003) Trade liberalization, growth and poverty reduction: the case of Bangladesh, South Asia region discussion paper, Report No. IDP-190, World Bank.

Aigner, D. J., Lovell, C. A. K., and Schmidt, P. (1977) Formulation and estimation of stochastic frontier production function models, Journal of Econometrics, 6, 21-37.

Alauddin, M., and Tisdell, C. (1987) Trends and projections for Bangladeshi food production: an alternative viewpoint, Food Policy, 12, 318-31.

Bangladesh Bureau of Statistics (BBS), Statistical Yearbook, several issues.

BBS, Bangladesh Agricultural Census, 1977, 1984 and 1997, Statistical Division, Ministry of Planning, Government of Bangladesh.

Boyce, J.K. (1987) Trends and projections for Bangladeshi food production: rejoinder to M. Alauddin and C. Tisdell, Food Policy, 12, 332-36.

Coelli, T., Rahman, S., and Thirtle, C. (2002) Technical, allocative, cost and scale efficiencies in Bangladesh rice cultivation: A non-parametric approach, Journal of Agricultural Economics, 53, 607-26.

Dembele, N., and Staatz, J. (2002) The Effects of Market Reform on Agricultural Transformation in Mali, in T. S. Jayne, I. Minde, \& G. Argwings-Kodhek (Eds.), Perspectives on agricultural transformation: A view from Africa. Nova Science Publishers, Huntington, NY.

Dercon, S. (2001) Economic reform, growth, and the poor: evidence from rural Ethiopia, Working Paper, Center for Study of African Economies Oxford.

Economic Intelligents Unit (EIU) (2000) Bangladesh: Country Economic Profile, UK.

Farrell, M. J. (1957) Measurement of productive efficiency, Journal of the Royal Statistical Society, 3, 253-81.

Food and Agricultural Organization (FAO) (2001) Production Yearbook, Vol. 55.

Griffiths, W. E. (1972) Estimation of actual response coefficients in the Hildreth-Houck random coefficient model, Journal of American Statistical Association, 67, 633-35.

Haghiri, M, Nolan, J. F. and Tran, K. C. (2004) Assessing the impact of economic liberalization across countries: a comparison of dairy industry efficiency in Canada and the USA, Applied Economics, 36, 1233-43.

Hildreth, C., and Houck, J. P. (1968) Some estimators for a model with random coefficients, Journal of American Statistical Association, 63, 584-95.

Huang, Y. and Kalirajan, K. P. (1997) Potential of Chaina’s grain production: evidence from the household data, Agricultural Economics, 17, 191-99.

Iraizoz, B., Bardaji, I., and Rapun, M. (2005) The Spanish beef sector in the 1990s: impact of the BSE crisis on efficiency and profitability, Applied Economics, 37, 473-84. 
Jayne, T. S., Govereh, J., Mwanaumo; A., Nyoro; J. K. and Chapoto, A. (2002) False promise or false premise? The experience of food and input market reform in Eastern and Southern Africa, World Development, 30, 341-58.

Kalirajan, K. P., and Obwona, M. B. (1994) Frontier production function: the stochastic coefficient approach, Oxford Bulletin of Economics and Statistics, 56, 87-96.

Kalirajan, K.P. and Shand, R.T. (1999) Frontier production functions and technical efficiency measures, Journal of Economic Surveys, 13, 149-71.

Kompas, T. (2002) Market reform, productivity and efficiency in Vietnamese rice production', (mimeo), National Centre for Development Studies, Australian National University.

Kumbhakar, S. C. and Lovell, C. A. K. (2000) Stochastic frontier analysis, Cambridge University Press, Cambridge.

Latruffe, L., Balcombe, K., Davidova, S., and Zawalinska, K. (2004) Determinants of technical efficiency of crop and livestock farms in Poland, Applied Economics 36, 1255-63.

Liu, Z. and Zhuang, J. (2000) Determinants of technical efficiency in Chinese agriculture: evidence from farm-level data, (mimeo) London Guildhall University.

Maddala, G. S., 1977, Econometrics, McGraw Hill, New York.

Meeusen, W., and van den Broeck, J. (1977) Efficiency estimation from Cobb-Douglas production functions with composed error, International Economic Review, 18, 435-44.

Ministry of Agriculture (MOA) (2003) Towards the sustainable agriculture, (mimeo), Government of Bangladesh.

Pray, C.E. (1980) An assessment of the accuracy of the official agricultural statistics of Bangladesh, Bangladesh Development Studies, 7, 1-38.

Rahman, S. H. (1992) A new tariff structure for agricultural equipment inputs, Final Report, TA No. 140009-BAN, Asian Development Bank.

Rahman, S. (2003) Profit efficiency among Bangladeshi rice farmers, Food Policy, 28, 487-502.

Rezitis, A. N., Tsiboukas, K. and Tsoukalas, S. (2002) Measuring technical efficiency in the Greek Agricultural sector, Applied Economics 34, 1345-57.

Schwallie, D. P. (1982) Unconstrained maximum likelihood estimation of contemporaneous covariances, Economic Letters, 9, 359-64.

Sharif, N.R. and Dar, A. (1996) An empirical study of the patterns and sources of technical inefficiency in traditional and HYV rice cultivation in Bangladesh, Journal of Development Studies, 32, 612-29.

Shidu, S. S. and Baanante, C. A. (1981) Estimating farm-level input demand and wheat supply in the Indian Punjab using a translog profit function, American Journal of Agricultural Economics, 63, 237-46.

Swamy, P. A. V. B. (1971) Statistical inference in random coefficient regression models, New York, Springer-Verlag.

Tybout, J. R. (1990) Making noisy data sing: Estimating production technologies in developing countries, Journal of Econometrics, 53, 25-44.

Wadud, A., and White, B. (2000) Farm household efficiency in Bangladesh: a comparison of stochastic frontier and DEA methods, Applied Economics, 32, 1665-73. 
World Bank, (1994) Bangladesh: From stabilization to growth, South Asia department Report 12724-BD, Washington, D. C.

Wu, S., Devadoss, S. and Lu, Y. (2003) Estimation and decomposition of technical Efficiency for Sugarbeet Farms, Applied Economics, 35, 471-84. 